\title{
Cash Holdings in Shariah-Compliant Firms
}

\author{
Muhammad Saiful Hakim ${ }^{1,2 *}$, Chih Liang Liu${ }^{1}$, Aang Kunaifi ${ }^{2}$ \\ ${ }^{1}$ Department of Finance, National Yunlin University of Science and Technology, Chinese Taipei \\ ${ }^{2}$ Department of Business Management, Institut Teknologi Sepuluh Nopember, Surabaya, Indonesia \\ Email: *ms_hakim@mb.its.ac.id
}

How to cite this paper: Hakim, M. S., Liu, C. L., \& Kunaifi, A. (2021). Cash Holdings in Shariah-Compliant Firms. Theoretical Economics Letters, 11, 47-55. https://doi.org/10.4236/tel.2021.111003

Received: December 11, 2020

Accepted: February 1, 2021

Published: February 4, 2021

Copyright (C) 2021 by author(s) and Scientific Research Publishing Inc. This work is licensed under the Creative Commons Attribution International License (CC BY 4.0).

http://creativecommons.org/licenses/by/4.0/ (c) (i) Open Access

\begin{abstract}
The restrictions of a shariah-compliant index could have consequences for corporate finance. This research investigates the difference in cash holding policies between shariah-compliant and conventional firms in the Indonesia capital market. Our empirical results suggest that a shariah-compliant firm holds significantly less cash compared to a conventional firm. The empirical finding still maintains after excluding top performers in the market and after controlling for other proxies of cash holdings and shariah-compliant firms. Our results suggest that the reputation benefit from a shariah-compliant index could outpace the cost of restrictions under a lenient shariah regulation environment.
\end{abstract}

\section{Keywords}

Cash Holding, Shariah-Compliant Firm, Shariah Index

\section{Introduction}

This research investigates the difference in cash holding policies between shariahcompliant firms and conventional firms in the Indonesia market. Since 2012, Indonesia has moved forward in the shariah investment market by introducing a shariah-compliant index. The index consists of firms listed in the Indonesia stock exchange that satisfy qualitative (halal principle in business operation) and quantitative (financial ratio or measure) criteria. Compare with similar index in other country quantitative criteria for Indonesia shariah index are lest stricter because they only consider two criteria, the ratio of debt based on interest (riba) over total and the ratio of interest revenue or non-halal revenue, the portion of debt from the asset while the other index includes the quick asset ratio criteria. As a result, there is more Indonesian company that conform to that listed in this index. The strand of the literature on Islamic finance has resolutely presented 
the importance of screening criteria in determining the characteristics of shariah firms (Ashraf \& Khawaja, 2016; Charles, Darné, \& Pop, 2015).

Prior scholars in the shariah compliance literature have investigated the impact of shariah index restrictions on corporate finance (Alnori \& Alqahtani, 2019; Rizvi, Arshad, \& Alam, 2015). Nevertheless, empirical evidence in regards to cash holdings is still limited. Bugshan, Alnori and Bakry (2020) study the Middle East and North Africa (MENA) region, documenting a higher cash holding level for sharia-compliant firm. They argue that shariah-compliant firms mitigate the restriction they carry by holding more cash. Arguably, one critical restriction in shariah-compliant firms is that they must attain a certain level of leverage. Thus, we expect a shariah-compliant firm to hold more cash as a substitute for a lower debt level (John, 1993).

There contrarily could be a case that a shariah-compliant firm holds less cash compared to its counterpart. A line of the literature has suggested that shariah compliance usually defines a healthy, growth-oriented firm that exhibits positive momentum (Mohammad \& Ashraf, 2015; Nobi, Singh, \& Aggarwal, 2019). Hence, there is little chance that a firm with excellent performance will face difficulty finding external financing. Therefore, based on the trade-off theory we expect such a firm to hold less cash. Moreover, the higher restriction for a shariah-compliant firm could also encourage it to infuse a culture of transparency and accountability, which have a substantial impact on its financial health (Pepis \& de Jong, 2019). Furthermore, the restriction on the level of cash in a shariah-compliant index could be why a shariah-compliant firm maintains a lower level of cash holding (Farooq \& Tbeur, 2013).

We perform our empirical analysis using a sample of Indonesian firms between 2016 and 2019 and select Indonesia, because it presents unique conditions to examine how firms manage their cash holdings under less strict shariah-screening environments. The results of our study suggest that shariah-compliant firms could be associated with a lower level of cash holdings compared with conventional firms. The empirical findings still hold after controlling for different proxies for cash holdings and shariah-compliant firms and after resolving the issue with the top performers in the market.

The contribution of our study is that we provide evidence that shariah-compliant firm did not always restrict firm financing. The findings could be an essential motivation for the company for listed in shariah-compliant index. This research contributes to the line of research by complements prior cash holding research in shariah-compliant firms (Bugshan et al., 2020) by investigating the issue in a more flexible shariah-compliant restriction environment. The difference between our research and Bugshan et al. (2020) is the research focus. Their research is more focused on the year time speed of adjustment for cash. Our attention in the study is on the cash fluctuation that existing in the quarter-year time period.

The remainder of the paper proceeds as follows. Section 2 describes the data 
and research design. Section 3 presents the results. Section 4 concludes.

\section{Method}

\subsection{Data}

We employ quarterly firm data from Indonesia by taking data provided by TICMI (The Indonesia Capital Market Institute). The shariah index data are extracted from a publication issued by the Indonesia Stock Exchange (IDX). Our study period starts from the $1^{\text {st }}$ quarter of 2016 until the $3^{\text {rd }}$ quarter of 2019 (total of 15 quarters). The initial data in this study consist of 7394 observations. After excluding financial service firms and eliminating missing data, our data comprise 5172 quarter-firm observations.

\subsection{Measurement}

The dependent variable in this study is cash holding, measured by the ratio of cash over total assets. The independent variable is the shariah index, defined as a dummy variable taking the value of 1 if listed in the shariah index and 0 otherwise. We use the Indonesia Sharia Stock Index (ISSI), which covers shariah-compliant stocks listed on IDX and included in the list of Islamic Securities (DES) issued by IDX. The ISSI constituents are re-selected twice a year, following the DES review schedule every May and November. DES is comprised of shariah stocks that have been selected by a shariah board and which meet shariah criteria under the DES review. The shariah board is part of Indonesia's financial market authority, OJK (Otoritas Jasa Keuangan). The data used for the review consists of the $2^{\text {nd }}$ quarter firm financial statement, the $4^{\text {th }}$ quarter firm financial statement, and the information disclosed by the firm to the authority. Some firms are included or excluded from the sharia-compliant index at the end of the selection period.

The criteria for the shariah index are regulated by the Indonesia Stock Exchanges supervisory regulation, which was promulgated in 2012. There are two conditions for equities to be selected as shariah stocks in Indonesia. The first condition is that the shariah firm should stay away from activities that are forbidden under Islam (haram). The haram activities include borrowing and lending on an interest basis (riba), gambling (maiser), production and distribution of alcohol (khamar), farming and processing of haram products, trading that violates shariah law, excessive risk-taking such as insurance and derivatives (gharar), and trading through bribery (risywah). The second requirement for shariah equities is that the financial ratio from equities should satisfy a few criteria. The first requirement is that the ratio of debt based on interest (riba) over total assets should not exceed $45 \%$. The second criterion is that the ratio of interest revenue or non-halal revenue over total revenue should not exceed $10 \%$.

We adopt several control variables based on prior research suggesting the direct effect toward cash holdings. The control variable consists of leverage, which is the ratio of total liabilities scaled by total assets. We also add the quadratic 
term of leverage, following prior research by Guney et al. (2007), who suggested that the relationship between cash holdings and leverage is non-monotonic. A higher level of leverage could also increase the likelihood for a firm to experience financial distress. The cost of debt is defined by financing expenses over total expenses (Opler, 1999). The next control variable is working capital, or total current assets minus current liabilities scaled by total assets (Al-Najjar \& Belghitar, 2011). Dividend is the dummy variable that equal 1 if firm pay dividend and 0 otherwise (Al-Najjar \& Belghitar, 2011; Bigelli \& Sánchez-Vidal, 2012). CAPEX is the proportion of capital expenditure scaled by total expenses (Chen, 2008). ROA is return on assets. Size is log assets (Subramaniam, Tang, Yue, \& Zhou, 2011).

Table 1 shows the descriptive statistics of the variables. The left side of the table reports them in the conventional firm (non-shariah-compliant), while the right side shows them for the shariah-compliant sub-sample. The descriptive table shows that majority of firms are listed in the shariah-compliant index. More than $60 \%$ of the firms (3421 from 1751) from a total sample are in the index. The mean of cash holding in the shariah-compliant firm is significantly lower (0.08) compared to the mean of cash holding in a conventional firm (0.09). The median in the shariah-compliant firm is also lower, but the Wilcoxon test did not suggest a significant difference.

Further, the Univar statistic also suggests that the mean (0.46) and median (0.47) of leverage for a shariah-compliant firm is significantly lower compared with the mean (0.490 and median (0.50) of leverage from the conventional firm. Meanwhile, we discover that the mean and median values for working capital, dividend, capital expenditure, ROA, and size significantly higher in a shariah-compliant firm.

Table 1. Descriptive statistics.

\begin{tabular}{|c|c|c|c|c|c|c|c|c|c|c|c|}
\hline \multirow{2}{*}{ Variable } & \multirow{2}{*}{$\mathbf{N}$} & \multicolumn{5}{|c|}{ Conventional Firm $(\mathrm{N}=1751)$} & \multicolumn{5}{|c|}{ Shariah-Compliant Firm $(\mathrm{N}=3421)$} \\
\hline & & Mean & Median & SD & Min & $\operatorname{Max}$ & Mean & Median & SD & Min & $\operatorname{Max}$ \\
\hline Cash Holdings & 5172 & 0.09 & 0.06 & 0.10 & 0.00 & 0.83 & $0.08^{\star *}$ & 0.05 & 0.09 & 0.00 & 0.80 \\
\hline Leverage & 5172 & 0.49 & 0.50 & 0.21 & 0.00 & 1.00 & $0.46^{* * *}$ & $0.47^{\star * *}$ & 0.20 & 0.00 & 1.00 \\
\hline Cost of Debt & 5172 & 0.03 & 0.02 & 0.03 & 0.00 & 0.61 & 0.03 & 0.02 & 0.02 & 0.00 & 0.25 \\
\hline Working Capital & 5172 & 0.05 & 0.03 & 0.21 & -0.77 & 0.89 & 0.07 & $0.04^{* *}$ & 0.20 & -0.68 & 0.87 \\
\hline Dividend & 5172 & 0.34 & 0.00 & 0.47 & 0.00 & 1.00 & $0.36^{*}$ & 0.00 & 0.48 & 0.00 & 1.00 \\
\hline Capital Expenditure & 5172 & 0.02 & 0.01 & 0.04 & 0.00 & 0.43 & $0.03^{* * *}$ & $0.01^{* * *}$ & 0.04 & 0.00 & 0.56 \\
\hline ROA & 5172 & 0.02 & 0.01 & 0.06 & -0.53 & 0.43 & $0.03^{* *}$ & $0.02^{* * *}$ & 0.06 & -0.60 & 0.53 \\
\hline Size & 5172 & 28.83 & 28.83 & 1.52 & 18.99 & 32.49 & $28.7^{* * *}$ & $28.75^{* * *}$ & 1.73 & 18.96 & 32.55 \\
\hline
\end{tabular}

This table presents the descriptive statistic for each variable based on the membership as shariah compliant-firm or conventional firm. Shariah Index is dummy variable that represent firm listed in shariah index. Leverage is the debt to asset ratio, the cost of debt is defined by financing expenses over total expenses. Working capital is total current assets minus current liabilities scaled by total assets. Dividend is the dummy variable that equal 1 if firm pay dividend and 0 otherwise. CAPEX is the proportion of capital expenditure scaled by total expenses, ROA is return on assets, size is log assets. The asterisk sign in Mean column represent the result of T-Test difference, the asterisk sign in Median column report the result of Wilcoxon signed rank test. The $\star^{\star *}$, ${ }^{\star *}$, and * denote significance at the $1 \%, 5 \%$, and $10 \%$ levels, respectively. 
Table 2. Correlation matrix.

\begin{tabular}{|c|c|c|c|c|c|c|c|c|c|}
\hline & $\begin{array}{c}\text { Cash } \\
\text { Holding }\end{array}$ & $\begin{array}{l}\text { Islamic } \\
\text { Index }\end{array}$ & Leverage & $\begin{array}{c}\text { Cost of } \\
\text { Debt }\end{array}$ & $\begin{array}{l}\text { Working } \\
\text { Capital }\end{array}$ & Dividend & $\begin{array}{c}\text { Capital } \\
\text { Expenditure }\end{array}$ & ROA & Size \\
\hline Cash Holding & 1 & & & & & & & & \\
\hline Islamic Index & $-0.0303^{*}$ & 1 & & & & & & & \\
\hline Leverage & $-0.2751^{\star}$ & $-0.0651^{\star}$ & 1 & & & & & & \\
\hline Cost of Debt & $-0.1746^{*}$ & 0.0053 & $0.1196^{*}$ & 1 & & & & & \\
\hline Working Capital & $0.0276^{\star}$ & $0.0349^{*}$ & $-0.3924^{\star}$ & $-0.0661^{\star}$ & 1 & & & & \\
\hline Dividend & $0.1837^{\star}$ & 0.0189 & $-0.0940^{*}$ & 0.0138 & $0.1049^{*}$ & 1 & & & \\
\hline Capital Expenditure & 0.0249 & $0.0333^{*}$ & $-0.0407^{\star}$ & $0.1457^{*}$ & $-0.1129^{*}$ & $0.1502^{*}$ & 1 & & \\
\hline ROA & $0.2788^{\star}$ & 0.0238 & $-0.2159^{*}$ & $-0.1430^{*}$ & $0.1568^{*}$ & $0.3999^{*}$ & $0.1498^{*}$ & 1 & \\
\hline Size & $0.0291^{\star}$ & $-0.0365^{*}$ & $0.1698^{*}$ & $-0.0415^{*}$ & $-0.1245^{*}$ & $0.1921^{\star}$ & $-0.0550^{*}$ & $0.0598^{*}$ & 1 \\
\hline
\end{tabular}

This table presents the pearson correlation coefficient between any pair of variables. Shariah Index is dummy variable that represent firm listed in shariah index. Leverage is the debt to asset ratio, the cost of debt is defined by financing expenses over total expenses, Working capital is total current assets minus current liabilities scaled by total assets. Dividend is the dummy variable that equal 1 if firm pay dividend and 0 otherwise. CAPEX is the proportion of capital expenditure scaled by total expenses, ROA is return on assets, size is log assets. The asterisk sign $\left({ }^{*}\right)$ represent the significant value of $1 \%$ of pearson correlation. 
Table 3. Regression estimating the cash holding.

\begin{tabular}{|c|c|c|}
\hline \multirow{2}{*}{ Variable } & (1) & (2) \\
\hline & \multicolumn{2}{|c|}{ Cash Holdings } \\
\hline \multirow{2}{*}{ Shariah Index } & $-0.0105^{\star * *}$ & $-0.00536^{\star *}$ \\
\hline & $(-5.36)$ & $(-2.48)$ \\
\hline \multirow{2}{*}{ Leverage } & $-0.286^{\star * *}$ & $-0.306^{\star * *}$ \\
\hline & $(-9.16)$ & $(-9.79)$ \\
\hline \multirow{2}{*}{ Leverage Square Term } & $0.139^{\star * *}$ & $0.155^{\star * *}$ \\
\hline & $(4.58)$ & (5.1) \\
\hline \multirow{2}{*}{ Cost of Debt } & $0.0797^{\star *}$ & 0.00969 \\
\hline & $(2.44)$ & $(0.25)$ \\
\hline \multirow{2}{*}{ Working Capital } & $-0.192^{\star * *}$ & $-0.189^{\star * \star}$ \\
\hline & $(-23.36)$ & $(-23.17)$ \\
\hline \multirow{2}{*}{ Dividend } & $-0.00574^{* * *}$ & $-0.00656^{* * *}$ \\
\hline & $(-3.04)$ & $(-3.15)$ \\
\hline \multirow{2}{*}{ Capital Expenditure } & $-0.0789^{* * *}$ & $-0.101^{\star \star \star}$ \\
\hline & $(-3.51)$ & $(-4.35)$ \\
\hline \multirow{2}{*}{ ROA } & $0.0726^{\star \star \star}$ & $0.0559^{* * *}$ \\
\hline & $(4.42)$ & $(3.33)$ \\
\hline \multirow{2}{*}{ Size } & $0.00680^{* *}$ & $0.0140^{* * *}$ \\
\hline & $(1.97)$ & $(3.79)$ \\
\hline Firm Effect & Yes & Yes \\
\hline Period Effect & No & Yes \\
\hline $\mathrm{N}$ & 5172 & 5172 \\
\hline$r^{2}$ & 0.128 & 0.141 \\
\hline
\end{tabular}

This table show the panel regression estimation for cash holding. Our variable of interest is Shariah Index is dummy variable that represent firm listed in Shariah Index. Leverage is the debt to asset ratio, The cost of debt is defined by financing expenses over total expenses, Working capital is total current assets minus current liabilities scaled by total assets. Dividend is the dummy variable that equal 1 if firm pay dividend and 0 otherwise. CAPEX is the proportion of capital expenditure scaled by total expenses, ROA is return on assets, size is log assets. Panel 1 reported the estimation of cash holding using panel regression without including period effect. Panel 2 reported the estimation of cash holding without period effect. Period effect is the variable that represents control for each quarterly year variation. Statistics are in parentheses where $p<$ $0.10,{ }^{* *} p<0.05$, and ${ }^{* *} p<0.01$.

The descriptive statistics offer evidence that the shariah-compliant index consists of firms with better performance and a more significant dividend payment amount. Consequently, a firm with excellent profitability is associated with a lower level of cash holdings. Profitable firms also have a higher possibility to pay dividends to increase their credibility and access to finance (Myers \& Majluf, 1984). Al-Najjar and Beghitar (2011) further proposed that dividend payment can exhibit an excellent reputation to investors, leading to greater access to capi- 
tal and hence lower cash holdings.

A firm may face both benefits and costs to be listed in the shariah-compliant index. One benefit is that they could have access to more investors who pay attention to their shariah-compliance status. On the contrary, a disadvantage relates to the firm's restriction in now it manages its business. Moreover, since the criteria for shariah compliance in Indonesia are more flexible compared with other regions, we are confident to suggest that firms will enjoy more benefits to their reputation rather than any difficulty that may arise from restrictions in the shariah index. Prior scholars of Islamic finance have outlined the importance of the screening criteria employed in a shariah index for determining the corporate finance decisions of shariah firms (Ashraf \& Khawaja, 2016; Masih, Kamil, \& Bacha, 2018).

To ensure that our findings are robust, we target a range of different specifications. First, we exclude the top performers $\left(20^{\text {th }}\right.$ percentile of the highest ROA in the market). The second measure we use is an alternative measurement for cash holdings by following Opler (1999) and Ozkan and Ozkan (2004). The last thing is that we utilize different criteria for shariah compliance by excluding firms that are not listed continuously in the shariah-compliant index. We discover consistent results with our main empirical results after embracing these robustness tests.

\section{Conclusion}

This research investigates the determinant of cash holdings in shariah-compliant firms and compares it with non-shariah-compliant firms. The empirical results show that firms in a shariah-compliant index hold lower cash levels than nonshariah-compliant firms. The findings are still robust after excluding top performers in the market, an alternative measurement of cash holdings, and alternative criteria for shariah compliance. We believe that the results herein are because the more flexible criteria for the shariah-compliant index in Indonesia provide fewer restrictions for firms in managing their financing and operations. At the same time, they are able to enjoy the benefits of being shariah-compliant firms in terms of a better reputation.

This study has shown the difference between a sharia-compliant firm and a conventional firm in managing corporate finance. However, our study is limited by the potential for endogeneity. We have addressed this problem through the use range of the robustness test. But indeed, we cannot completely rule out the possibility that endogeneity still existed.

\section{Conflicts of Interest}

The authors declare no conflicts of interest regarding the publication of this paper.

\section{References}

Al-Najjar, B., \& Belghitar, Y. (2011). Corporate Cash Holdings and Dividend Payments: 
Evidence from Simultaneous Analysis. Managerial and Decision Economics, 32, 231-241. https://doi.org/10.1002/mde.1529

Alnori, F., \& Alqahtani, F. (2019). Capital Structure and Speed of Adjustment in NonFinancial Firms: Does Sharia Compliance Matter? Evidence from Saudi Arabia. Emerging Markets Review, 39, 50-67. https://doi.org/10.1016/j.ememar.2019.03.008

Ashraf, D., \& Khawaja, M. (2016). Does the Shariah Screening Process Matter? Evidence from Shariah Compliant Portfolios. Journal of Economic Behavior and Organization, 132, 77-92. https://doi.org/10.1016/j.jebo.2016.10.003

Bigelli, M., \& Sánchez-Vidal, J. (2012). Cash Holdings in Private Firms. Journal of Banking and Finance, 36, 26-35. https://doi.org/10.1016/j.jbankfin.2011.06.004

Bugshan, A. S., Alnori, F., \& Bakry, W. (2020). Shariah Compliance and Corporate Cash Holdings. SSRN Electronic Journal, 1-40. https://doi.org/10.2139/ssrn.3581440

Charles, A., Darné, O., \& Pop, A. (2015). Risk and Ethical Investment: Empirical Evidence from Dow Jones Islamic Indexes. Research in International Business and Finance, 35, 33-56. https://doi.org/10.1016/j.ribaf.2015.03.003

Chen, Y. R. (2008). Corporate Governance and Cash Holdings: Listed New Economy versus Old Economy Firms. Corporate Governance: An International Review, 16, 430-442. https://doi.org/10.1111/j.1467-8683.2008.00701.x

Farooq, O., \& Tbeur, O. (2013). Dividend Policies of Shariah-Compliant and NonShariah-Compliant Firms: Evidence from the MENA Region. International Journal of Economics and Business Research, 6, 158. https://doi.org/10.1504/IJEBR.2013.055537

Guney, Y., Ozkan, A., \& Ozkan, N. (2007). International Evidence on the Non-Linear Impact of Leverage on Corporate Cash Holdings. Journal of Multinational Financial Management, 17, 45-60. https://doi.org/10.1016/j.mulfin.2006.03.003

John, T. A. (1993). Accounting Measures of Corporate Liquidity, Leverage, and Costs of Financial Distress. Financial Management, 22, 91. https://doi.org/10.2307/3665930

Masih, M., Kamil, N. K. M., \& Bacha, O. I. (2018). Issues in Islamic Equities: A Literature Survey. Emerging Markets Finance and Trade, 54, 1-26. https://doi.org/10.1080/1540496X.2016.1234370

Mohammad, N., \& Ashraf, D. (2015). The Market Timing Ability and Return Performance of Islamic Equities: An Empirical Study. Pacific Basin Finance Journal, 34, 169-183. https://doi.org/10.1016/j.pacfin.2015.07.001

Myers, S. C., \& Majluf, N. S. (1984). Corporate Financing and Investment Decisions When Firms Have Information That Investors Do Not Have. Journal of Financial Economics, 13, 187-221. https://doi.org/10.1016/0304-405X(84)90023-0

Nobi, K., Singh, M., \& Aggarwal, A. (2019). Corporate Attributes Influencing the Compliance of Islamic Finance: Evidence from Listed Companies under Shariah Index in India. Theoretical Economics Letters, 9, 1744-1771. https://doi.org/10.4236/tel.2019.96112

Opler, T. (1999). The Determinants and Implications of Corporate Cash Holdings. Journal of Financial Economics, 52, 3-46. https://doi.org/10.1016/S0304-405X(99)00003-3

Ozkan, A., \& Ozkan, N. (2004). Corporate Cash Holdings: An Empirical Investigation of UK Companies. Journal of Banking and Finance, 28, 2103-2134. https://doi.org/10.1016/j.jbankfin.2003.08.003

Pepis, S., \& de Jong, P. (2019). Effects of Shariah-Compliant Business Practices on Long-Term Financial Performance. Pacific Basin Finance Journal, 53, 254-267. 
https://doi.org/10.1016/j.pacfin.2018.11.002

Rizvi, S. A. R., Arshad, S., \& Alam, N. (2015). Crises and Contagion in Asia Pacific-Islamic v/s Conventional Markets. Pacific Basin Finance Journal, 34, 315-326. https://doi.org/10.1016/j.pacfin.2015.04.002

Subramaniam, V., Tang, T. T., Yue, H., \& Zhou, X. (2011). Firm Structure and Corporate Cash Holdings. Journal of Corporate Finance, 17, 759-773.

https://doi.org/10.1016/j.jcorpfin.2010.06.002 